who had had a subtotal thyroidectomy but who were normocalcaemic.

In each group about one-third of the patients without objective laryngeal signs complained of persistent voice changes dating from the time of operation.

Our thanks are due to the various physicians and surgeons who referred patients for study. We are grateful to Associate Professor T. S. Reeve for his helpful advice and criticism. Miss Felicity Johnson gave valuable clerical assistance.

This work was supported by the Postgraduate Medical Foundation, University of Sydney, the N.S.W.. State Cancer Council, Messrs. Farmer Hill Pty. Ltd., and Messrs. Geigy (Australasia).

\section{RBFERENCES}

Albright, F., and Reifenstein, E. C. (1948). The Parathyroid Glands and Metabolic Bone Disease. Williams and Wilkins, Baltimore.
Blackburn, G., and Salmon, L. F. W. (1961). Brit. F. Surg., 48, 371. Blomstedt, B. (1959). Acta chir. scand., 118, 97. - and Rydmark, K. E. (1960). Acta oto-laryng. (Stockh.), 52, 150. Borgstrom, S. (1956). Acta ckir. scand., 111, 351.

Buckwalter, J. A., Soper, R. T., Davies, J., and Mason, E. E. (1955).

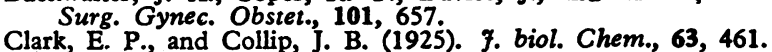

Dent, C. E., (1962). Brit. med. Ұ., 2, 1419.

Durham, C. F., and Harrison, T. S. (1964). Surg. Gynec. Obstet., 118, 38.

Fales, F. W. (1953). 7. biol. Chem., 204, 577.

Fourman, P., Davis, R. H., Jones, K. H., Morgan, D. B., and Smith, J. W. G. (1963). Brit. F. Surg, 50, 608

Girling, J. A., and Murley, R. S. (1963). Brit. med. 7., 1, 1323.

Hagan, P. J. (1963). Ann. Otol. (St. Louis), 72, 206.

Hawe, P., and Lothian, K. R. (1960). Surg. Gynec. Obstet., 110, 488.

Ranke, E. J., and Holinger, P. H. (1955). 7. Amer. med. Ass., 158, 543.

Reeve, T. S. (1964). Paper read at Annual Meeting, Endocrine Society of Australia, Canberra.

Riddell, V. H. (1956). Lancet, 2, 638.

Roy, A. D., Gardiner, R. H., and Niblock, W. M. (1956). Ibid., 1, 988. Technicon Instruments Corporation (1960). Modified Method for Calcium Determination, Chauncey, N.Y.

Thorén, A., and Wi nbladh, H. (1956). Acta endocr. (Kbh.), 22, 224.

Wade, J. S. H. (1960). Brit. F. Surg., 48, 25.

\title{
Tissue Concentration of Nalidixic Acid in Chronic Pyelonephritis
}

\section{R. M. JAMESON,* F.R.C.S.}

Brit. med. F., 1965, 2, 621-622

Chronic pyelonephritis is as common as ever although chemotherapeutic agents and antibiotics have adequate in vitro bactericidal effects. One probable reason for the failure of such agents to eradicate pyelonephritis is an insufficient concentration of the bactericidal agent in the kidney tissue. The aim of treatment is to eradicate parenchymal and tubular infection as well as to produce sterile urine.

Nalidixic acid (Negram) has been used to treat urinary-tract infections (Lishman and Swinney, 1963; Barlow, 1963; Jameson and Swinney, 1963 ; Ward-McQuaid et al., 1963 ; Swinney, 1964). The results obtained were encouraging and led to the study of the tissue concentration of nalidix acid in the pyelonephritic kidney.

\section{Materials and Methods}

Elective nephrectomy is an accepted procedure in chronic pyelonephritis, and volunteers from the waiting-list for nephrectomy provided the tissue used in this study. In each case the chronic pyelonephritis was associated with stone, hypertension, hydronephrosis, or recurrent infection. All the patients had urinary infections due to Escherichia coli or proteus-type organisms on admission. In every instance the organisms were sensitive to nalidixic acid, and urine cultures were negative on the day of operation and after seven days' treatment. Premedication samples of blood and urine were obtained for control from each volunteer before administration of $1 \mathrm{~g}$. of nalidixic acid six-hourly. At varying time intervals during treatment nephrectomy was performed, and the renal tissue, blood, and urine concentrations of nalidixic acid measured. Samples of renal tissue from four untreated patients were analysed to act as controls for the series.

After nephrectomy an obviously diseased area of the kidney was removed and divided into cortical and medullary blocks each about 1-2 c.cm. in size. These two samples were dried with blotting-paper, placed into clean dry jars, and sent with

\footnotetext{
* Senior Registrar, Department of Urology, Newcastle upon Tyne General Hospital.
}

the blood and urine specimens for analysis. Care was taken that the adjacent tissue was submitted for histological study. The spectrophotofluorimetric technique described (McChesney et al., 1964) measures free and protein-bound nalidixic acid; the biologically inactive metabolites are not determined.

During this investigation the opportunity arose to measure nalidixic acid concentrations in blood, urine, kidney, and pus in a man with externally draining renal suppuration who later underwent nephrectomy.

\section{Results}

All 11 patients had proved chronic pyelonephritis and infections of the urinary tract which responded to treatment with nalidixic acid. The infecting organisms found were: coliform and proteus type in six, coliform in three, and proteus type in two.

The control group of patients who did not receive treatment grew $E$. coli from their urine before nephrectomy. No apparent nalidixic acid was found in the blood, urine, or kidney tissue.

The levels of nalidixic acid in the renal cortex and medulla, blood, and urine after treatment with the drug at the dose of $1 \mathrm{~g}$. six-hourly are shown in Table I. One patient not included

TABLE I.-Levels of Unconjugated Nalidixic Acid in the Renal Cortex

\begin{tabular}{|c|c|c|c|c|c|c|}
\hline \multirow[b]{2}{*}{$\begin{array}{l}\text { Case } \\
\text { No. }\end{array}$} & \multirow[b]{2}{*}{$\begin{array}{c}\text { Days of } \\
\text { Medication } \\
\text { (1 g. } \\
6 \text {-hrly) }\end{array}$} & \multirow[b]{2}{*}{$\begin{array}{l}\text { Plasma } \\
\text { (mg./1.) }\end{array}$} & \multicolumn{3}{|c|}{ Kidney } & \multirow[b]{2}{*}{$\begin{array}{c}\text { Urine } \\
\text { (mg./1.) }\end{array}$} \\
\hline & & & $\begin{array}{c}\text { Cortex } \\
(\mathbf{m g} . / \mathrm{kg} .)\end{array}$ & $\begin{array}{c}\text { Medulla } \\
\text { (mg./kg.) }\end{array}$ & $\begin{array}{c}\text { Average } \\
\text { Renal } \\
\text { Tissue } \\
\text { (mg./kg.) }\end{array}$ & \\
\hline $\begin{array}{r}1 \\
2 \\
3 \\
4 \\
5 \\
6 \\
7 \\
8 \\
9 \\
10 \\
11\end{array}$ & \begin{tabular}{|l|}
1 \\
2 \\
2 \\
3 \\
4 \\
5 \\
6 \\
7 \\
8 \\
6 weeks \\
4 months \\
\end{tabular} & $\begin{array}{c}1 \cdot 8 \\
3.8 \\
2.5 \\
20.5 \\
1 \\
\text { No sample } \\
9 \\
1 \\
30 \\
<1 \\
<1\end{array}$ & $\begin{array}{c}15 \\
8 \\
15 \\
8.5 \\
6.1 \\
3.2 \\
1.8 \\
1.0\end{array}$ & $\begin{array}{r}2 \overline{15} \\
5.7 \\
11.3 \\
10.5 \\
8.8 \\
6.0 \\
4.5 \\
3.8\end{array}$ & $\begin{array}{c}2.2 \\
18 \\
6.9 \\
13.2 \\
5.3 \\
9.5 \\
7.5 \\
4.6 \\
3.7 \\
0.6 \\
2.4\end{array}$ & $\begin{array}{l}123 \\
49 \\
180 \\
174 \\
180 \\
102 \\
89 \\
576 \\
440 \\
130 \\
1\end{array}$ \\
\hline
\end{tabular}


in the series had severe mephralgia which failed to respond to conservative measures. She volunteered to take a course of nalidixic acid before nephrectomy. The level of nalidixic acid in the normal renal cortex was $20 \mathrm{mg} . / \mathrm{kg}$., in the medulla 18 $\mathrm{mg} . / \mathrm{kg}$. In this patient and in all those in the series negligible concentrations were found in skin, subcutaneous fat, and muscle.

The urine levels of unconjugated nalidixic acid vary during the day but remain at an average level of $300 \mathrm{mg} . / 24$ hours, as calculated from the 24-hour urine specimens.

The data obtained from a patient with a perinephric abscess who later had a nephrectomy are shown in Table II.

TABle II.-Plasma, Urine, Pus, and Kidney-tissue Levels of Nalidixic Acid from a Patient with a Perinephric Abscess. Treated with Nalidixic Acid for Five to Six Weeks

\begin{tabular}{|c|c|c|c|c|}
\hline $\begin{array}{l}\text { Days of } \\
\text { Medication } \\
\text { (1 g. 6-hrly) }\end{array}$ & $\begin{array}{l}\text { Plasma } \\
\text { (mg./1.) }\end{array}$ & $\underset{\text { (mg./I.) }}{\text { Urine }}$ & $\underset{\text { (mg./l.) }}{\text { Pus }}$ & $\begin{array}{c}\text { Kidney } \\
\text { (mg./kg.) }\end{array}$ \\
\hline $\begin{array}{r}0 \\
5 \\
6 \\
7 \\
8 \\
9 \\
10 \\
36\end{array}$ & $\begin{array}{c}<1 \\
6 \\
7 \cdot 5 \\
10 \cdot 5 \\
8 \\
11 \cdot 5 \\
1\end{array}$ & $\begin{array}{r}<1 \\
79 \\
240 \\
226 \\
212 \\
130\end{array}$ & $\begin{array}{l}\overline{-} \\
\overline{8} \\
24 \\
20^{*} \\
=\end{array}$ & $\begin{array}{l}\overline{ } \\
\bar{z} \\
\overline{0.6}\end{array}$ \\
\hline
\end{tabular}

* Pus sterile on 9th day of treatment.

\section{Discussion}

The present treatment of chronic pyelonephritis is disappointing. To eradicate infection the antibacterial agent must be given in sufficient dosage for a sufficient time to produce a bactericidal concentration in the blood and kidney tissue, irrespective of the state of diuresis or renal function (Schlegel, 1962a). A few studies of the concentration of antibacterial agents in renal tissue of animals have been carried out. From these it was found that sulphanilamide and sulphamethizole did not concentrate in rat renal tissue in spite of high blood and urine levels (Schlegel, 1962b). The renal concentration of sulphonamides is low, but the renal-cortex/plasma ratio for nalidixic acid is eight to one in the rat (Schlegel, 1962a). In the monkey nalidixic acid has a high concentration in the kidney but no marked affinity for any other tissue (McChesney et al., 1964).

Renal-tissue concentrations of antibiotics have not been reported in man. The estimation of drug levels in diseased human tissue is of fundamental importance, but such studies raise ethical problems. In the present investigation all the volunteers required nephrectomy. Because infection was present all needed antibacterial therapy (cf. Swinney and Hammersley, 1963), and they understood the concern to take the opportunity to determine the renal concentration of an antibacterial drug of known value.

The results, shown in Table I, suggest that the concentration of nalidixic acid in the plasma and renal tissue may rise after 24 hours' treatment. Since seven of the 11 patients had renaltissue levels greater than those found for the corresponding plasma it seems likely that nalidixic acid concentrates in the diseased human kidney. In Table I there is little difference between medullary and cortical levels. This series is too small to prove that a significant difference may exist between the medullary and cortical concentrations of nalidixic acid in man.

Although the urinary concentrations of nalidixic acid vary during the day, the average daily excretion of unconjugated nalidixic acid is about $300 \mathrm{mg} . / 24$ hours. Others confirm this finding and note that active bactericidal levels are obtained (Buchbinder et al., 1962).

One patient (Case 11) had four months' treatment before nephrectomy; she had previously taken her own discharge after a pyeloplasty. When she eventually agreed to have the kidney removed it was found to have multiple upper-pole abscesses with an obstruction of the upper major calix. This case demonstrates that free drainage must be obtained before a urinary infection can be cured by antibiotic treatment.

The data shown in Table II indicate that nalidixic acid is found in pus, which in the patient concerned was sterile on the ninth day of treatment. When the kidney was removed it was noted that its tissues were replaced by a fibrous mass.

The results obtained from the two patients receiving longterm treatment are difficult to explain; it is possible that nalidixic acid is bound to inflamed tissues, as reported with the synthetic penicillins. This could be established only by further study.

In-vitro disk-sensitivity tests showed that all the organisms in the series were sensitive to a minimum inhibitory concentration (M.I.C.) of $15 \mu \mathrm{g}$. of nalidixic acid per ml. Deitz (1962) records an average M.I.C. of $7.5 \mu \mathrm{g}$. $/ \mathrm{ml}$. for the $E$. coli group and an M.I.C. of $7.5-10 \mu \mathrm{g} . / \mathrm{ml}$. for the Proteus mirabilis group. The Proteus vulgaris has a higher M.I.C. of about $20 \mu \mathrm{g} . / \mathrm{ml}$. Froelich (1962) notes that biologically active levels in human plasma and urine are obtained about $20 \mathrm{mg} . / 1$. As nalidixic acid may be bound to plasma protein the active level in man would be the M.I.C. as determined by in-vitro tests plus approximately $20 \mu \mathrm{g} . / \mathrm{ml}$.

\section{Summary}

Nalidixic acid is of value in the treatment of urinary infections, and in this study its concentration in the human pyelonephritic kidney was measured. Samples of blood, urine, and renal tissue were obtained from volunteers requiring elective nephrectomy. The nalidixic-acid level was assayed by a spectrophotofluorimetric technique. The results suggest that nalidixic acid may be concentrated in the pyelonephritic kidney.

I wish to thank Mr. J. Swinney for his help and encouragement in permitting publication of the results obtained from patients under his care, and Dr. R. Norton and the staff of the Public Health Laboratory for their assistance. I acknowledge the invaluable help given by $\mathrm{Mr}$. A. Robertson in performing the spectrophotofluorimetric essays. I thank Dr. G. Hill and Mr. H. Hurst of the Bayer Products Company for their help, and the Bayer Products for the supply of nalidixic acid (Negram) tablets used in this investigation.

\section{REFERENCES}

Barlow, A. M. (1963). Brit. med. 7., 2, 1308. Buchbinder, M., Webb, J. C. Anderson, L. U., and McCabe, W. R.

Deitz, W. H. (1962). Data in the Files of the Sterling Winthrop Institute. Froelich, E. J. (1962). Ibid.

Jemeson, R. M. (1965). Brit. 7. Urol. In press.

and Swinney, J. (1963). Ibid., 35, 122 .

Lishman, I. V., and Swinney, J. (1963). Ibid., 35, 116.

McChesney, E. W. Froelich, E. J., Lesher, G. Y., Crain, A. V. R.,

McChesney, E. W. Froelich, E. J., Lesher, G. Y., Crain,
and Rosi, D. (1964). Toxicol. appl. Pharmacol., 6, 292.

Schlegel, J. U. (1962a). Y. Ark. med. Soc., 59, 215 . Biology, 1962.

Biolugy, 1962. Practitioner, 192, 701 .
Swinney, J. (1964). Prok of Operative Urological Surgery, p. 9 . Livingstone, Edinburgh.

Ward-McQuaid, J. F. N. C., Jichlinski, D., and Macis, R. (1963). Brit. med. ., 2, 1311 . 